\title{
Family Literacy and Revitalization of Islamic Values In Indonesia
}

\author{
Tubagus Chaeru Nugraha ${ }^{1 *}$, Rosaria Mita Amalia², Fahmy Lukman¹, Davidescu Cristiana ${ }^{3}$ \\ ${ }^{1}$ Arabic Literature, Faculty of Humanities, Universitas Padjadjaran, Bandung, Indonesia \\ ${ }^{2}$ English Literature, Faculty of Humanities, Universitas Padjadjaran, Bandung, Indonesia \\ ${ }^{3}$ Russia Literature, Faculty of Humanities, Universitas Padjadjaran, Bandung, Indonesia
}

ARTICLE INFO

\section{Keywords}

Family Literacy, Functional

Islamic Values, Revitalization

Strategies

\section{${ }^{*}$ Correspondence}

t.chaeru@unpad.ac.id

\section{Article History}

Received 7 January 2021

Accepted 3 April 2021

Published online 5 April 2021

\begin{abstract}
The industrial revolution 4.0 disrupts the technology field and other fields, such as law, economics, and society, namely the deprivation of human values and religion. One of the steps to overcome the disruption era is the revitalization of Islamic values, given that the majority of Indonesia's population is Muslim. Islamic values are fundamentally built in the family as the smallest social structure of society. Therefore, this study aims to describe the strategy of the revitalization of Islamic values in the family. To achieve this goal, a descriptive analysis method is used. To obtain accurate results, this study was conducted in three steps. First, the provision of data with the method of conversation with questionnaire techniques about Islamic values in the family which one of the members is the student. Second, the analytical method used is the eclectic SWAT-functional method. Using SWAT-analysis as one of the methods, the strengths, weaknesses, threats, and challenges of the family to revitalize Islamic values in the era of disruption can be mapped, while using the functional analysis, it can be given the principles of Islamic families. Then, the analyzed data is compiled as a strategy to revitalize Islamic values in the family. Third, the presentation of data informally, namely providing a straightforward explanation of optimizing Strengths-opportunities and strategies to overcome weaknesses (weakness-threats) to revitalize Islamic values in the family. The results of the study were found two types of Indonesian families based on the eight family functions in the Qur'an. Type-A, a good family and strong, namely the fulfillment of family functions between $70 \%$ to $90 \%$. The type-B family is not good and not strong because religion and education are not good. This research implies that a strategy is needed to optimize the value of Islamic values in the type $\mathrm{A}$ family and strengthen the religiosity function and educational function in the type B family.
\end{abstract}

\section{INTRODUCTION}

According to Chadijah (Chadijah, 2018), the family is the smallest social system in society, consisting of the father, mother, and child. Mawardi (Mawardi, 2017), Fauzia (Fauzia, 2019)added that one of the family's functions to form the good and strong character for first and foremost educators the younger generation. However, in the era of industrial revolution 4.0, according to Simamora (Simamora, 2019), disruption is not only in technology but also in other fields, such as law, economics, and social, namely human values and religion.

In fact, according to Murphy (MURPHY, 2018), disruption will occur with disruptive regulation, disruptive culture, disruptive mindset, and disruptive marketing. The characters of a disruptive mindset can be described as follows: (1) Quick response, not hampered; (2) Real-time, once received, immediately processed; (3) Follow-up, immediately followed up, not postponed; (4) Looking for a way, not a dead step; (5) Sniffing information and truth, not accepting without testing; (6) Parallel, not serial solutions; (7) Information technology is supported, not manually. To overcome the era of disruption (uprooting of people from important values), it is necessary to revitalize the humanities' role as a basis for reference in developing technology. The idea hopes that technology increasing will not deprive of human values, including Islamic values.

Among the challenges of revitalizing Islamic values in a family in the disruption era is that family members spend more time on the internet and digital media. According to Komunikasi and Indonesia (2014), at least 30 million children and adolescents in Indonesia are Internet and digital media users. As a result, there are conflicts in relationships between family members. Lee (Lee, 2020) 's concern is that unresolved conflict risks drug use, drinking alcohol, and symptoms of depression.

() 2021 by the authors; Association of Indonesian Moslem Scholar, Hannover, Germany. This is an Open Access article distributed under the terms of the Creative Commons Attribution-ShareAlike 4.0 International License. (https://creativecommons.org/licenses/by-sa/4.0/), which permits unrestricted use, distribution, and reproduction in any medium, provided the original work is properly cited. 
Through their study, Radjagukguk (Radjagukguk, 2020) suggests harmonious family communication is the best way for parents to socialize or revitalize essential values, including Islam, in everyday life. It hasn't mapped the strengths, weaknesses, obstacles, and challenges to become a harmonious family until now. Therefore, this study aims to describe the type of family and the strategy of revitalizing Islamic values in Muslim families whose members are students in West Java and Indonesia's surroundings.

In a previous study, Ranggyoni (Ranggayoni et al., 2020)explained that Islamic religiosity or Islamic values lead a person to get true happiness by optimizing self-potential, independence, good relations, and knowing the solutions to all problems. Then Musikanski and Carlsen (Musikanski et al., 2017), (Carlsen, 2018)mention there are ten variables of happiness index. The ten variables include (1) work, (2) household income, (3) housing and asset conditions, (4) education, (5) health, (6) family harmony, (7) social relations, (8) availability of leisure time, (9) environmental conditions, and (10) security conditions. The results of his research show that increasing Human Development Index (HDI) can create happiness and welfare for Indonesia's people. It will happen by adding affective dimensions and meanings of life.

According to Anderson (Anderson et al., 2017), family literacy positively affects children's language development. Based on the study of family literacy programs, using two languages can significantly increase knowledge. Furthermore, Swain (Swain \& Cara, 2019) has successfully conceptualized the family literacy environment into four areas. Literacy at home includes literacy: 1) family resources; 2) literacy behavior and parents' attitudes; 3) parents' beliefs and understanding; 4) family literacy activities and practices.

In 2019, Kim (Kim \& Song, 2019) based on his observation that multilingual family literacy can maximize family knowledge. In addition, the participation of family members (parents, children, and extended family/community members) collectively builds a larger communicative repertoire. This can enhance unique linguistic, multimodal, and cultural abilities and experiences. In 2020 , in the Philippines Tatel (Tatel-Suatengco \& Florida, 2020) has described family literacy practices centered on parent-child interactions that can encourage information literacy. According to his observations, family literacy practices based on family values and aspirations can motivate each family member to pursue a better education.

According to Kaiper (Kaiper-Marquez et al., 2020) the COVID-19 pandemic has led to extraordinary family literacy teaching changes. This family literacy pandemic discusses how teachers create online learning opportunities for parents and children to learn together, the strategies and resources instructors use to teach remotely, how challenges such as discomfort with technology are handled, and what has been learned from experience.

Based on these previous studies, there has been no family literacy research that focuses on beliefs in religious values. Furthermore, (Nugraha et al., 2019) formulated Prophet Muhammad's family model as the best source of Islamic values in the family. Based on the interpretation of the 'an and the Sunnah (Syihabuddin, 2017) (Mustopa, 2017), (Muttaqin, 2019) the family model of Rasul Allah SAW is obtained. Namely, there are five purposes, three principles, eight functions, and five happiness in the family. The eight family functions of the Apostle of Allah are (1) religious function, that is, the family provides beliefs, knowledge, worship, experience, and actualization of Islamic values to the members; (2) educational functions provide education to all family members; (3) affective function, place of mutual affection; (4) family reproductive function, which is produced by legitimate offspring and observations; (5) economic functions fulfilled basic family needs (food, clothing, shelter); (6) social functions of families, respectable and dignified families; (7) protective function, which is to protect the family from physical, economic, and psycho-social threats; and (8) recreational functions, making the family a recreation center for its members. The eight family functions are very influential on the achievement of the five types of happiness, namely (1) material, (2) sexual or affection, (3) moral, (4) intellectual, and (5) spiritual. Based on the previous research mentioned above, this study aims to describe the type of Indonesian family based on the eight functions of the family. Then, describe the right strategy for revitalizing Islamic values according to the type of Indonesian family.

\section{RESEARCH METHODS}

This research uses the descriptive analysis method. Following the opinion of Mahsun (Mahsun, 2014) this research is carried out in three steps. First, the provision of data with the method of conversation with questionnaire techniques about Islamic values in the family. Second, the analytical method used is the eclectic SWAT-functional method. This is following Arafat's opinion (Arafat, 2019), describing the description of objects that are examined through sample or population data as they are. Third, presenting data with an explanation of strategies for optimizing strengths and strategies to overcome weaknesses to revitalize Islamic values in the family

\subsection{Sample}

The participants are students of the Faculty of Cultural Sciences, Universitas Padjadjaran, between 19 and 22 years. The total sample is 100 people, consisting of 65 female students and 35 male students from 900 people. The number of 100 comes from two study programs, A 60 (40 female students and 20 male students) study program B 40 (25 female students and 15 male students). They come from 21 cities and districts in West Java, Banten, and Jakarta.

\subsection{Measurement Tools}

This study's measurement tools a modification of the scale of the family function used by Cierpka (Cierpka, 2014) with the variable eight functions of the Islamic family by Nugraha et al. (2019). The eight family functions of the Apostle of Allah are (1) religious function, (2) educational functions, (3) affective functions, (4) reproductive functions, (5) economic functions, (6) social functions, (7) protective functions, and (8) recreational function. The size scale per point is (1) very good (> 80\%), (2) good (67-80\%), (3) quite good (55-66\%), (4) less good (40-55\%), (5) Not good $(<40 \%)$.

\subsubsection{Questionnaire}

Questionnaires are arranged based on the scale of Islamic family functions (Nugraha et al., 2019). Table 1 in the form of a statement according to the Apostle of God's eight family functions. From Table 1, the questionnaire on the eight functions of Islamic families, data is obtained from 100 family respondents. The data findings are analyzed in the discussion section. 


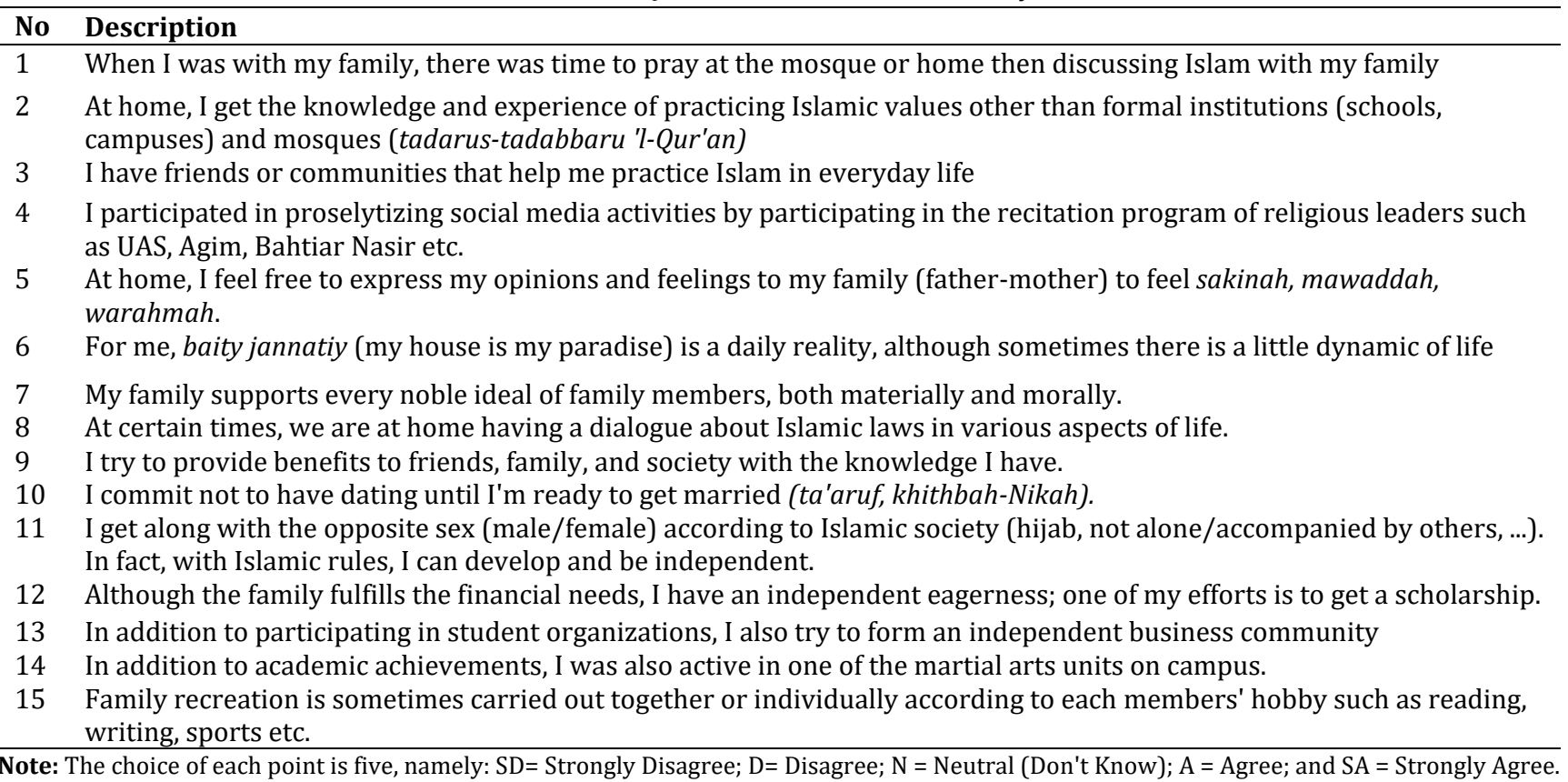

\section{RESULTS AND DISCUSSIONS}

The results of the class A and B questionnaires are combined in Table 2. Results of Islamic family 8-F Questionnaire. Based on the results of questionnaire table 2 of two classes A and B, there are different perceptions of Islamic values' reality in their families. Class A's perception shows a tendency to agree on Islamic values, even though there are $20 \%$ of values they do not know (neutral). Whereas, in class B there is a tendency for $53 \%$ not to know and not to approve some points of the function of Islamic values in their families. Based on these data, it needs to be classified between types A and B families.

Table 2. Results of islamic family 8-F Questionnaire (in percentage)

\begin{tabular}{|c|c|c|c|c|c|c|c|c|c|c|c|c|c|c|c|}
\hline \multirow{2}{*}{ NO } & \multicolumn{5}{|c|}{ Combined AB (\%) } & \multicolumn{5}{|c|}{ Туре A (\%) } & \multicolumn{5}{|c|}{ Туре В (\%) } \\
\hline & SD & $\mathrm{D}$ & $\mathrm{N}$ & A & SA & SD & $\mathrm{D}$ & $\mathrm{N}$ & A & SA & SD & D & $\mathrm{N}$ & A & SA \\
\hline 1 & 2 & 9 & 37 & 35 & 17 & 0 & 7 & 38 & 32 & 23 & 5 & 13 & 35 & 40 & 8 \\
\hline 2 & 0 & 4 & 13 & 41 & 42 & 0 & 2 & 10 & 35 & 53 & 0 & 8 & 18 & 50 & 25 \\
\hline 3 & 2 & 7 & 17 & 41 & 33 & 2 & 0 & 2 & 45 & 52 & 3 & 18 & 40 & 35 & 5 \\
\hline 4 & 7 & 19 & 33 & 22 & 19 & 0 & 0 & 37 & 35 & 28 & 18 & 48 & 28 & 3 & 5 \\
\hline 5 & 5 & 6 & 22 & 30 & 37 & 2 & 2 & 17 & 37 & 43 & 10 & 13 & 30 & 20 & 28 \\
\hline 6 & 4 & 5 & 17 & 32 & 42 & 2 & 3 & 10 & 27 & 58 & 8 & 8 & 28 & 40 & 18 \\
\hline 7 & 1 & 4 & 12 & 32 & 51 & 2 & 3 & 12 & 28 & 55 & 0 & 5 & 13 & 38 & 45 \\
\hline 8 & 4 & 8 & 17 & 36 & 35 & 2 & 0 & 5 & 38 & 55 & 8 & 20 & 35 & 33 & 5 \\
\hline 9 & 8 & 25 & 12 & 30 & 25 & 2 & 0 & 8 & 48 & 42 & 18 & 23 & 18 & 3 & 43 \\
\hline 10 & 21 & 11 & 22 & 20 & 26 & 3 & 2 & 22 & 33 & 40 & 48 & 25 & 23 & 0 & 5 \\
\hline 11 & 5 & 14 & 31 & 23 & 27 & 0 & 3 & 20 & 33 & 43 & 30 & 48 & 8 & 3 & 0 \\
\hline 12 & 1 & 2 & 19 & 33 & 45 & 2 & 2 & 8 & 28 & 60 & 0 & 3 & 35 & 40 & 23 \\
\hline 13 & 7 & 23 & 41 & 19 & 10 & 2 & 18 & 45 & 22 & 13 & 0 & 3 & 35 & 40 & 23 \\
\hline 14 & 18 & 43 & 27 & 7 & 5 & 2 & 0 & 15 & 38 & 45 & 38 & 48 & 5 & 3 & 8 \\
\hline 15 & 5 & 6 & 18 & 34 & 37 & 2 & 0 & 15 & 38 & 45 & 10 & 15 & 23 & 28 & 25 \\
\hline
\end{tabular}

\subsection{Family Type $A$}

Based on Table 2, Type A respondents' results regarding the eight family functions of the questionnaire, so that it is easy to understand, then graph-1 type family A. Figure 1 is based on the function scale and the number of respondents. Herewith is the explanation of the details of the results of the family questionnaire A. The type of family A based on family functions are as follows:

1) Religious functions (Qs.51:56), the tendency for prayer services in the mosque for men (Qs.2:43) and women at home (45 to $60 \%$ ) to 'good enough. Transfer of knowledge and experience in practicing Islamic values (Qs.2:132) towards 'very good' (8890\%). The Islamic environment (Qs.14:37) is 'very good' (95-98\%). Actively participate in passive-active preaching (Qs.25:74) on social media towards 'good enough' (53-65\%). So the average (Rf) religious function is 'good'.

2) Affective function (Qs.30:21), feeling comfortable, mutual love, and mutual affection between family members on average 'good' (78-80\%), attaining a home atmosphere like in the 'good' world paradise (80-81\%) and feeling get moral support and 'very good' material (80-90\%). So the average (Af) affective function is 'good.'

3) Educational functions (Qs.58:11), dialogue about 'very good' Islamic law (93\%), and independent learning about Islamic law towards 'very good' (88-95\%). So the average (Ef) educational function is 'very good.

4) Social function (Qs.18:16), (Sf) contributes to a 'very good' environment (88-95\%).

5) The function of maintaining reproduction (Qs.17:32), commitment not to be 'good' dating (70-80\%), and maintaining 'good' Islamic association (76-80\%). So the average (Ref) reproductive function is 'very good.

6) Economic functions (Qs.3:73), family finances to 'very good' (83-90\%), and business eagerness(50\%) have not been known yet. There are (45\%) motivated by business. Although it has not been motivated by its development, the economic function is very good, so (Ef) is 'good'. 
7) Protective function (Qs.66:6), there are 80-83\% not motivated to participate, even though Pf is 'good'

8) Recreational functions (Qs.62:10), Recf (75-88\%) is 'very good'.

Based on the data above, the type of family A shows almost all family functions run with an 'excellent' average of educative, social, reproductive, and recreational functions, while the 'good' average for religious, affective, protective, and economic functions. It proves type A family is good and strong.

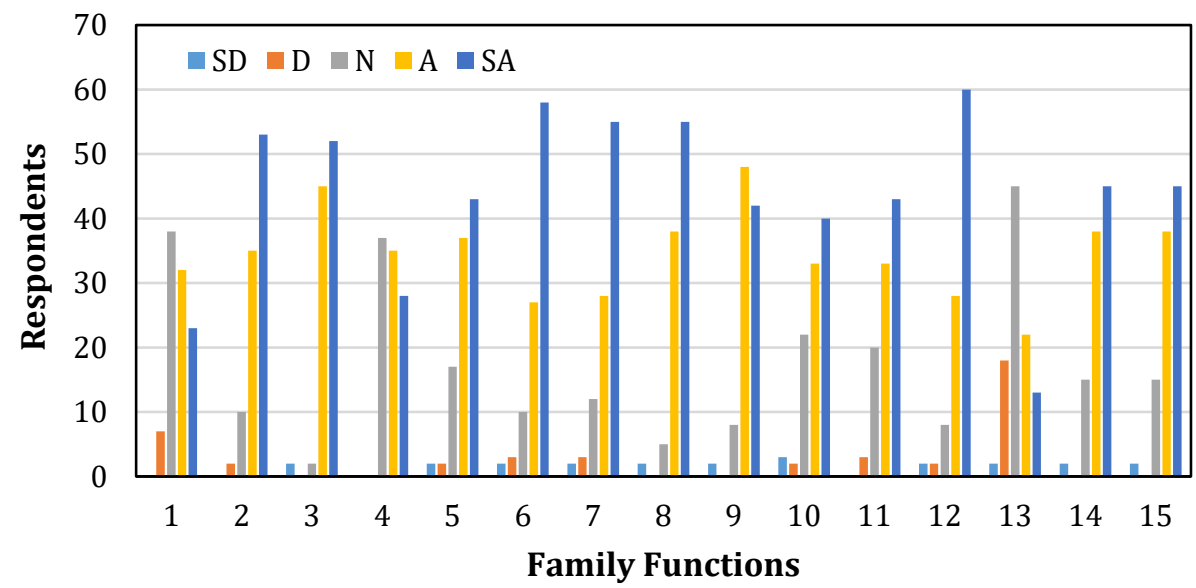

Figure 1. The type of family A: family function scale

\subsection{Family Type $B$}

Family type B is explained as follows,

1) Religious functions, the tendency for prayer services in the mosque for men and women at home (44-52\%) to be 'less good'. Transfer of knowledge and experience in practicing 'good' Islamic values (73-76\%). The Islamic environment determined 'good' (40-68\%). Actively participate in passive-active preaching on social media 'not good' (0-12\%). So the average (Rf) religious function is 'less good'.

2) Affective function, feeling comfortable, mutual love, and mutual affection among family members on average 'not good' (57$58 \%$ ), achievement of the atmosphere of the house is like in the paradise of the world 'less good' (47-64\%) and feelings of moral support and material 'very good' (80-84\%). So the average (Af) affective function is 'quite good'.

3) Educational functions, dialogue about 'bad' Islamic law (27-42\%) and independent learning about Islamic law towards 'not good' (0-4\%). So the average (Ef) educational function is 'not good'.

4) Social functions (Sf) contribute to the 'good enough' environment (54-67\%).

5) The function of maintaining reproduction, the commitment of not dating 'not good' (0-8\%) and keeping Islamic association 'not good' (8-13\%). So the average (Rf) reproductive function is 'not good'.

6) Economic functions, family finances determined 'good' (53-78\%) and the eagerness to do business (50-53\%) have not been yet motivated by business. The economic function is 'very good', so (Ef) is 'good'.

7) Protective function, $67-93 \%$ are not motivated to participate, even though Pf is 'good'

8) Recreational function, Recf (57-66\%) 'good enough'.

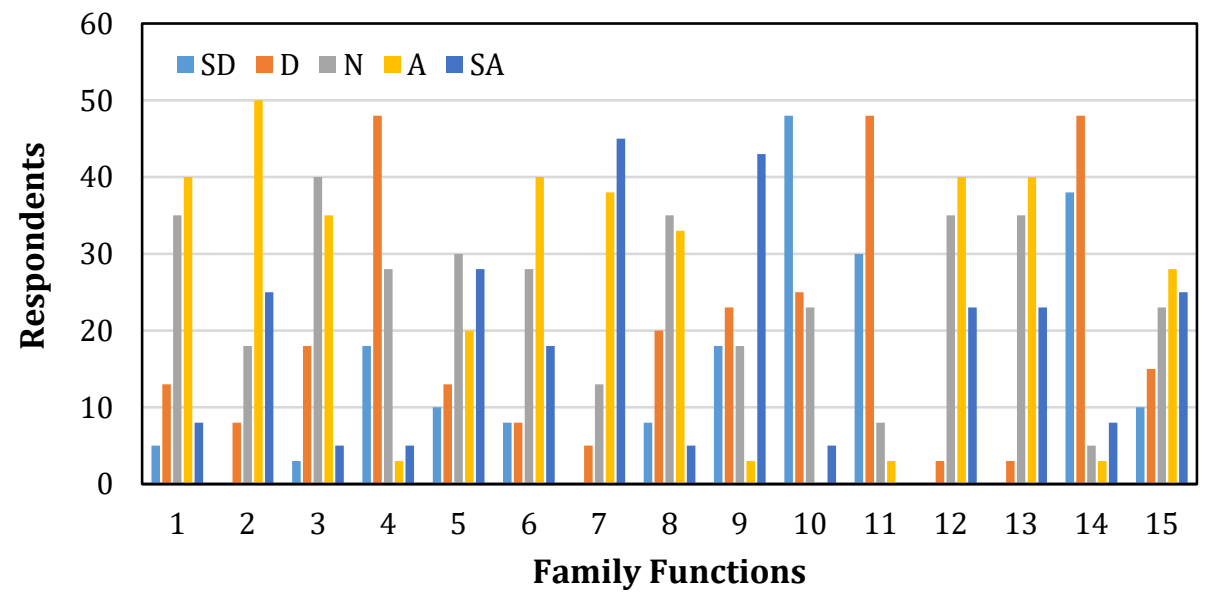

Figure 2. The type of family A: family function scale

Based on the data above and Figure 2, type B family has 'good' economic function and protection while practical and recreational functions are 'quite good', but there is religious-educational-function - keeping family reproduction 'not good'. It can be concluded that the type of family B is 'good enough', but it is not strong in applying Islamic values. 


\subsubsection{Reliability}

Based on the questionnaire, it is obtained that the level of reliability using Cronbach alpha from all items on the questionnaire measuring instrument of 0.905 . Therefore, it can be concluded that the questionnaire is very reliable to measure the level of family functionality. The followings are the level of reliability for each item: religious function (0.812), affective function (0.851), educative function (0.832), social function (0.822), Reproductive function (0.82), economic function (0.838), protective function (0.854), and recreational function (0.845).

\subsubsection{Validity}

Since a high level of validity on a measuring instrument/questionnaire is a great need, the existing questionnaire's constructs should be tested first. The Pearson's Correlation coefficient is used for the total score, and the following results are obtained. Table 3 shows Pearson's Correlation Coefficient.

Table 3. The Pearson's Correlation coefficient

\begin{tabular}{lll}
\hline Question item & $\begin{array}{l}\text { Correlation } \\
\text { coefficient }\end{array}$ & Information \\
\hline Religious Function-1 & $0.496^{*}$ & Valid \\
Religious Function -2 & $0.54^{*}$ & Valid \\
Religious Function -3 & $0.79^{*}$ & Valid \\
Religious Function -4 & $0.78^{*}$ & Valid \\
Affective Function -1 & $0.596^{*}$ & Valid \\
Affective Function -2 & $0.624^{*}$ & Valid \\
Affective Function -3 & $0.459^{*}$ & Valid \\
Educative Function -1 & $0.799^{*}$ & Valid \\
Social Function -1 & $0.847^{*}$ & Valid \\
Reproductive Function-1 & $0.816^{*}$ & Valid \\
Reproductive Function -2 & $0.761^{*}$ & Valid \\
Economic Function-1 & $0.638^{*}$ & Valid \\
Economic Function -2 & $0.452^{*}$ & Valid \\
Protective Function-1 & $0.507^{*}$ & Valid \\
Recreational Function-1 & $0.633^{*}$ & Valid \\
\hline \multicolumn{2}{c}{ *The coefficient is significant to the level of 99\% }
\end{tabular}

Based on Table 3, the correlation coefficient is quite high for the total score and compared with test statistics $\mathrm{r}_{0.05 / 2 ;(100-2)}=$ 0.1966 , then all items can be considered valid with a confidence level of up to $99 \%$ because all items reach a correlation value above the test statistic.

\subsection{Revitalization Strategy for Islamic Values}

According to (Hermawansyah \& Suryani, 2017) the strategy of internalizing Islamic values is by modeling and habituation. Meanwhile, according to (Tang, 2018) it is necessary to develop a learning strategy for Islamic Religious Education through integrative learning technology between Islamic values, science, and technology. Furthermore, (Nasrudin et al., 2018) have applied a polyculture strategy in integrated Natural Science learning with related Islamic values. His research concludes that the polyculture strategy can be used as an alternative to learning life sciences, which is more meaningful and more human. According to Siswanto et al. (Anisyah \& Siswanto, 2018), revitalizing the Koran values in the Islamic education system is a solution to maintain the swift flow of globalization and shifting the negative impact of the Industrial Revolution 4.0. Likewise, Anggraini (Anggraheni \& Astuti, 2020) states that the narrative of society 5.0 emerges with the concept of life that is technology-based and human-centered. Humans are positioned at the helm of technological developments. It takes Human Resources (HR), who is superior in academics and skills and ethics and personality. It's just that, Hermansyah, Tang, Siswanto, and Anggraini have not explained how the revitalization strategy in the family is.

As for the revitalization of Islamic values in the family, Nasiruddin has done it (Scourfield \& Nasiruddin, 2015). He researched 13 Muslim families in the UK using the interview method. As a result, the fathers agreed to the integration of Islamic values in the family. Then, in Malaysia, Azahari (Hadigunawan \& Azahari, 2017) discusses the implementation of Islamic values in the family. He tries to describe the neglect of Islamic values that causes family conflict. In Indonesia, Prasanti (Prasanti \& el Karimah, 2018), describes the communication process in the family to internalize Islamic values in the family. The result is that the communication patterns are as follows: (1) The role of parents as communicators is very dominant in Islamic family communication patterns. ; (2) religious values embedded in the Islamic family through the context of verbal and non-verbal messages, ranging from education, health, relationships, and Islamic lifestyle; (3) The existence of social media using Whatsapp Group in spreading messages containing religious values to other family members.

As for the research on the revitalization of Islamic values in Indonesian families, according to Ikhwan (Ikhwan et al., 2019) , the role of the family in internalizing Islamic values is carried out in three stages, namely: 1). value transformation, 2) value internalization, and 3). Transcendentalization of the value of the benefits of knowledge. According to Hanoum (Hanoum T., 2019, the sakinah family's indicator is that each family member will have a sense of affection, not prejudice, trust each other, respect each other, and advise each other.

Based on previous studies on the study of strategies for internationalizing Islamic values, education integration is needed, both formal, informal, and non-formal. In other words, education must be integrated both at home, in the environment, and at school. For good and strong family types, the strategy is to optimize Islamic values. The recommended steps include: (1) Family members join the community for the enrichment of Islamic sciences such as the interpretation of the Koran, the hadith of Rasulullah SAW, and the life experiences of the Prophet and his companions; (2) Choosing a community according to the interests where 
Islamic values have become a habit in that community; (3) family members familiarize themselves with congregational prayer both at the mosque and at home.

The type of family is quite good, and the strategy is strengthening Islamic values. The recommended steps include: (1) family recitation at home and participating in the recitation of local mosques; (2) familiarize family discussions about Islamic sciences with the local ustadz; (3) accustom family members to worship in congregation at home. The strategy of revitalizing Islamic values is the responsibility of family members, the Muslim community, and the role of the state in implementing and protecting Islamic values so that family harmony is created, internally and externally.

\section{CONCLUSION}

Based on previous research studies, data analysis, and discussion results, this study's two objectives have been achieved. First, based on the eight functions of Islamic families in Indonesia, there are two, namely Type A and Type B. Type A families, all family functions run well. As for the type B family, the function of education and religion is not good. The revitalization strategy for Islamic values in Indonesian families must be integrated into formal, non-formal, and informal education systems. The stages of education are the same: value transformation, value internalization, and simultaneous implementation between cognitive, affective, and psychomotor so that there is a harmony of Islamic values both in the household and in the community.

\section{ACKNOWLEDGEMENT}

This research is funded by the Ministry of Research and Higher Education (Kemenristekdikti). Thank you for all assistance to various parties, for the Dean of the Faculty of Cultural Sciences' permission, Rector of Universitas Padjadjaran, and his staff, especially DRPMI Unpad. Hopefully, this research results can improve cultural harmony and strengthen our identity as the Indonesian nation.

\section{References}

Anderson, J., Anderson, A., \& Sadiq, A. (2017). Family literacy programmes and young children's language and literacy development: Paying attention to families' home language. Early Child Development and Care, 187(3-4), 644-654.

Anggraheni, R., \& Astuti, R. D. (2020). Revitalisasi Nilai-Nilai Islami dalam Edukasi guna Mempersiapkan Generasi Menuju Era Society 5.0 sebagai Bagian dari Strategi Rekonstruksi Kejayaan Peradaban Islam. Prosiding Konferensi Integrasi Interkoneksi Islam Dan Sains, 2, 31-34.

Siswanto, S., \& Anisyah, Y. (2019). Revitalisasi Nilai-Nilai Qur'ani Dalam Pendidikan Islam Era Revolusi Industri 4.0. Islamuna: Jurnal Studi Islam, 5(2), 139-146.

Arafat, G. Y. (2019). Membongkar Isi Pesan dan Media dengan Content Analysis. Alhadharah: Jurnal Ilmu Dakwah, 17(33), 32-48.

Carlsen, L. (2018). Happiness as a sustainability factor. The world happiness index: a posetic-based data analysis. Sustainability science, 13(2), 549-571.

Chadijah, S. (2018). Karakteristik Keluarga Sakinah dalam Islam. Rausyan Fikr: Jurnal Pemikiran Dan Pencerahan, 14(1), 113-128.

Cierpka, A. (2014). Narrative identity of adolescents and family functioning. Psychology of Language and Communication, 18(3), 263.

Fauzia, S. A. (2019). Mewujudkan keluarga sakinah melalui bimbingan pra-nikah. Oetoesan-Hindia: Telaah Pemikiran Kebangsaan, 1(2), 47-58.

Hadigunawan, N., \& Azahari, R. (2017). Penghayatan Islam dan Hubungannya dengan Konflik Rumahtangga: Kajian di Unit Runding Cara, Bahagian Undangundang Keluarga, Jabatan Agama Islam Selangor. Jurnal Syariah, 24(3), 393-422.

Hanoum T., F. C. (2019). Implementasi Agama dalam Mewujudkan Keluarga Sakinah. As-Syar'i : Jurnal Bimbingan \& Konseling Keluarga, 1(1), 58-75 . https://doi.org/10.47467/as.v1i1.48

Hermawansyah, H., \& Suryani, S. (2017). Internalisasi Nilai-nilai Keislaman pada Anak-anak Para Muallaf. PALAPA, 5(1), 14-42.

Ikhwan, A., Biantoro, O. F., \& Rohmad, A. (2019). The Role of the Family in Internalizing Islamic Values. Dinamika Ilmu, 19(2), 323-335.

Kaiper-Marquez, A., Wolfe, E., Clymer, C., Lee, J., McLean, E. G., Prins, E., \& Stickel, T. (2020). On the fly: Adapting quickly to emergency remote instruction in a family literacy programme. International Review of Education, 1-23.

Kim, S., \& Song, K. H. (2019). Designing a community translanguaging space within a family literacy project. The Reading Teacher, 73(3), 267-279.

Lee, W. Y. (2020). Working transgenerationally: a clinical discussion on family dynamics and treatment. Journal of Family Therapy, 42(4), 499-517.

Mahsun, M. (2014). Metode Penelitian Bahasa: Tahapan, Strategi, dan Tekniknya. Jakarta: Raja Grafindo Persada.

Mawardi, M. (2016). Keluarga Sakinah: Konsep \& Pola Pembinaan. International Journal Ihya"Ulum al-Din, 18(2), 253-67.

Murphy, E. (2018). The "Strawberry Generation." Connecting Childhood and Old Age in Popular Media. https://doi.org/10.2307/j.ctv5jxmnf.10

Musikanski, L., Cloutier, S., Bejarano, E., Briggs, D., Colbert, J., Strasser, G., \& Russell, S. (2017). Happiness index methodology. Journal of Social Change, 9(1), 2.

Mustopa, M. (2017). Al-Sunnah dan Tafsir Alquran (Tinjauan tentang Fungsi dan Posisi al-Sunnah dalam Tafsir Alquran). Diya AlAfkar: Jurnal Studi al-Quran dan al-Hadis, 5(01), 19-38.

Muttaqin, A. (2019). Etika Sosial terhadap Difabel Netra: Analisis Semantik Alquran. INKLUSI Journal of Disability Studies, 6(1), 71-92.

Nasrudin, D., Suhada, I., Rochman, C., Helsy, I., \& Hermawan, A. H. (2018). Polyculture strategy: Integration of islamic values, national character, and local wisdom in science learning. In Proceedings of the International Conference on Islamic Education (ICIE 2018) (Vol. 261, No. ASSEHR, pp. 236-239). Atlantis Press.

Nugraha, T. C., Amalia, R. M., \& Darmayanti, N. (2019, January). Sustainability of family harmony through literacy of prophet Muhammad family model. In Achieving and Sustaining SDGs 2018 Conference: Harnessing the Power of Frontier Technology to Achieve the Sustainable Development Goals (ASSDG 2018) (pp. 142-149). Atlantis Press.

Prasanti, D., \& El Karimah, K. (2018). Internalisasi Nilai-Nilai Keagamaan dalam Membentuk Komunikasi Keluarga Islami di Era Digital. INFERENSI: Jurnal Penelitian Sosial Keagamaan, 12(1), 195-212. 
Radjagukguk, D. L. (2020). Pola Strategi Komunikasi Orang Tua Terhadap Anak Pada Era Digitalisasi (Studi: Warga Malinjo Pasar Minggu Jakarta Selatan). Syntax Literate; Jurnal Ilmiah Indonesia, 5(3), 43-52.

Ranggayoni, R., Munir, A., \& Meutia, C. (2020). Hubungan Religiusitas dan Persahabatan dengan Kebahagiaan pada Mahasiswa Sekolah Tinggi Agama Islam Negeri Gajah Putih Takengon. Tabularasa: Jurnal Ilmiah Magister Psikologi, 2(1), 48-55.

Scourfield, J., \& Nasiruddin, Q. (2015). Religious adaptation of a parenting programme: process evaluation of the F amily L inks I slamic V alues course for M uslim fathers. Child: care, health and development, 41(5), 697-703.

Simamora, S. L. (2019). Bina Karakter Dan Ahlak Di Era Teknologi Komunikasi Digital Pada Remaja Warga Bintara Jaya Iv, Bekasi Jaya, Bekasi. Prosiding Konferensi Nasional Pengabdian Kepada Masyarakat dan Corporate Social Responsibility (PKM-CSR), 2, 144-154.

Swain, J. M., \& Cara, O. (2019). Changing the home literacy environment through participation in family literacy programmes. Journal of Early Childhood Literacy, 19(4), 431-458.

Syihabuddin, S. (2016). Penerjemahan Teks Suci: Analisis Ketepatan Terjemahan Istilah Kecendekiaan Dalam Alquran dan Terjemahnya. Adabiyyāt: Jurnal Bahasa dan Sastra, 15(1), 87-109.

Tang, M. (2018). Pengembangan Strategi Pembelajaran Pendidikan Agama Islam (PAI) Dalam Merespon Era Digital. Fikrotuna, $7(1), 717-740$.

Tatel-Suatengco, R., \& Florida, J. S. (2020). Family literacy in a low-income urban community in the Philippines. Journal of Early Childhood Literacy, 20(2), 327-355. 